\title{
HUBUNGAN LINGKUNGAN MASYARAKAT DAERAH WISATA TERHADAP MOTIVASI BELAJAR SISWA SDN 8 TUK-TUK
}

\author{
Effendi Manalu
}

Surel: emanalu11@gmail.com

\begin{abstract}
ABSTRAK
Penelitian ini bertujuan untuk mengetahui hubungan lingkungan masyarakat daerah wisata terhadap motivasi belajar siswa SDN 8 Tuk-Tuk. Subjek penelitian berjumlah 70 siswa. Hasil penelitian diperoleh lingkungan masyarakat daerah wisata tergolong sedang, i dengan nilai rata-rata sebesar 14,8 dan standar deviasi sebesar 1,92. Sedangkan motivasi belajar siswa tergolong sedang, dengan nilai rata-rata 15,2 dan standar deviasi sebesar 2,93. Dari hasil perhitungan korelasi, lingkungan masyarakat daerah wisata berhubungan dengan motivasi belajar siswa yaitu $r_{x y}>r_{\text {tabel }}$ yaitu 0,289> 0,235 .
\end{abstract}

Kata Kunci: Hubungan Lingkungan, Daerah Wisata, Motivasi Belajar

\section{PENDAHULUAN}

Pendidikan senantiasa menjadi sorotan bagi masyarakat khususnya di Indonesia yang ditandai dengan adanya pembaharuan maupun eksperimen guna terus mencari kurikulum, sistem pendidikan, dan metode pengajaran yang efektif dan efisien. Berbicara tentang pendidikan berarti berbicara tentang manusia dengan segala aspeknya. Nilai suatu bangsa terletak dari kualitas sumber daya manusia yang menjadi warga Negara. Semakin baik kualitas manusianya, bangsa tersebut semakin memiliki peluang besar menuju kemajuan dan kemakmuran.

Motivasi dan belajar merupakan dua hal yang saling mempengaruhi. Motivasi yang rendah yang dimiliki peserta didik mengakibatkan rendahnya prestasi belajar peserta didik. Dan apabila hal ini dibiarkan terus menerus, maka peserta didik akan semakin kurang bersemangat belajarnya. Dalam rangka mencapai tujuan nasional, khususnya dalam bidang pendidikan, yang berupaya mencapai masyarakat adil dan makmur baik jasmani maupun rohani, perlu adanya usaha untuk menciptakan sumber daya manusia yang berkualitas, guna memenuhi kebutuhan pembangunan dewasa ini dan masa yang akan datang.

Untuk mencapai hal tersebut, perlu ditumbuhkan motivasi yang kuat untuk meraih sesuatu yang dicitacitakan. Motivasi yang kuat diharapkan dapat memacu meningkatkan kualitas dan potensi sumber daya manusia, khususnya prestasi dalam bidang pendidikan. Sebagaimana ditegaskan dalam pasal 4 UU No. 20 tahun 2003 tentang Sistem Pendidikan Nasional yang menyebutkan: pembangunan nasional

Dosen Jurusan PGSD Prodi PGSD UNIMED 
di bidang pendidikan adalah mengembangkan potensi peserta didik agar menjadi manusia yang beriman dan bertaqwa kepada Tuhan Yang Maha Esa, serta berakhlak mulia, sehat, berilmu, cakap, kreatif, mandiri, dan menjadi warga negara yang demoktratis serta bertanggung jawab.

Sumber daya manusia yang memiliki kecerdasan tinggi, yang ditunjang oleh adanya sikap dan perilaku yang bertaqwa terhadap Tuhan Yang Maha Esa, serta budi pekerti yang luhur, sangat diharapkan dalam rangka mencapai tujuan nasional. Di sisi lain adanya pengetahuan dan keterampilan, serta pola kepribadian yang mantap dan dinamis, juga dapat membantu tercapainya tujuan nasional yaitu membentuk manusia-manusia bertanggung jawab terhadap pembangunan bangsa. Adapun langkah yang harus ditempuh dalam upaya membantu mewujudkan tujuan di atas adalah dengan menumbuhkan dan membina motivasi kepada para pelaku pendidikan, terutama motivasi para siswa yang merupakan harapan bangsa untuk memacu prestasi dalam segala bidang, agar menjadi generasigenerasi yang siap dalam menghadapi tantangan masa kini dan masa yang akan datang.

Masih banyak siswa yang memiliki prestasi belajar yang rendah dan mengecewakan, hal tersebut diduga karena salah satu faktor penyebabnya adalah motivasi belajar siswa yang lemah dan tidak adanya rasa tanggung jawab terhadap pendidikan yang sedang siswa tempuh. Karena tidak adanya visi ke depan sebagai motivasi belajar untuk mempersiapkan diri menghadapi kehidupan di masa yang akan datang. Motivasi belajar anak cenderung dipengaruhi oleh lingkungan internal maupun eksternal. Lingkungan internal yang dimaksud adalah salah satunya lingkungan keluarga, sedangkan lingkungan eksternal yang dimaksud salah satunya adalah lingkungan budaya yaitu lingkungan pariwisata. Pariwisata merupakan sumber pokok pendapatan bagi banyak Negara. Objek wisata memang sangat cocok untuk dijadikan tempat berwirausaha. Selain sebagai objek wisata, masyarakat dapat juga membuka usaha di objek wisata sesuai dengan aturan yang dimiliki oleh lokasi-lokasi wisata yang telah ditetapkan. Dengan demikian masyarakat dapat memenuhi kebutuhannya dengan membuka usaha dilokasi wisata Danau Toba.

Pariwisata juga mendukung kegiatan pembangunan secara luas serta meningkatkan pendapatan daerah dan masyarakat bahkan memperbesar perolehan devisa negara. Pariwisata akan membuka usaha dan lapangan kerja seperti membuka warung makan, minimarket, kios souvenir dan usaha perhotelan. Perlu disadari bahwa lapangan pekerjaa e-ISSN 2355-1747 
disediakan oleh perusahaan industri, tetapi juga dapat melalui usaha sosial, pemberdayaan sektor informal atau wiraswasta dan/atau kegiatan yang menciptakan usaha. Hal inilah yang menjadi fenomena berkembangnya pariwisata di Provinsi Sumatera Utara khususnya di kabupaten Simanindo, yang banyak memfokuskan kegiatan pembangunan pada sektor pariwisata, dengan salah satu obyek pariwisata yaitu wisata Danau Toba yang terdapat di Samosir Kecamatan Simanindo.

Dari usaha yang dijalankan oleh masyarakat terutama masyarakat yang ada di kecamatan Simanindo akan menambah pemasukan bagi masyarakatnya dan semakin mudahnya dalam mendapatkan uang. Hal positif yang muncul yaitu bukan hanya orangtua saja yang mudah dalam mendapatkan uang tetapi anak juga dapat dengan mudah mendapatkan uang.

Di samping itu juga, ada beberapa kendala yang muncul yaitu, kurangnya motivasi belajar dari orangtua terhadap anaknya. Hal ini disebabkan karena kesibukan orangtua terhadap usaha yang dijalankan sehingga kurang memperhatikan anaknya dan juga mudahnya anak mendapatkan uang menyebabkan anak lebih tergiur untuk mencari uang dibandingkan dengan pergi ke sekolah.

Hal ini menyebabkan anak torikut untul horucaha sendiri dalam p-ISSN 2407-4934 e-ISSN 2355-1747 menghasilkan uang seperti menyewakan sepeda motor, menyewakan skuter, menyewakan sampan dan lain sebagainya. Sehingga anak memiliki waktu yang kurang untuk belajar dan tidak terfokus untuk mengikuti pembelajaran di sekolah. Oleh sebab itu, banyak anak yang lebih memilih untuk bekerja dibandingkan dengan melanjutkan sekolahnya ke jenjang yang lebih tinggi lagi. Begitu juga dengan orangtua yang seharusnya lebih memperhatikan keseriusan belajar dan hasil belajar anak ternyata lebih terfokus dalam menjalankan usahanya. Dengan keadaan seperti ini motivasi anak dalam belajar berkurang.

Selain dari penjelasan pada paragraf di atas, anak juga lebih banyak memiliki waktu bermain dibandingkan belajar. Hal ini di buktikan dengan banyak anak yang setelah pulang sekolah pergi bermain bersama teman-temannya seperti bermain bola, bermain kelereng dan berenang di danau sampai pada sore hari. Sering sekali anak lupa waktu untuk belajar karena peluang bermain untuk anak sangat besar, dan orangtua anak tidak berada di rumah tetapi berada di tempat orangtuanya bekerja. Dengan keadaan orangtuanya seperti itu, anak memiliki banyak kesempatan untuk pergi ke luar rumah. Kebanyakan bermain menyebabkan anak merasa kelelahan dan tidak belajar lagi setelah selesai bermain. 
Dengan keadaan anak yang sering terjadi seperti yang dijelaskan pada paragraf di atas, maka untuk mendapat nilai yang terbaik akan semakin kecil kemungkinannya.

Namun pada kenyataannya, untuk mencapai nilai yang maksimal, perlu adanya motivasi yang kuat ditumbuhkan kepada peserta didik, terutama dari orangtua yang sebagai orang terdekat siswa di dalam keluarga, agar para siswa selalu terdorong untuk mengembangkan potensi yang ada pada diri mereka. Hasil belajar anak dapat dilihat dari Daftar Kolektif Nilai Ujian Nasional siswa yaitu pada tahun ajaran 2012/2013 nilai rata-rata Bahasa Indonesia 8,62; Matematika 8,47; IPA 8,38 . Pada tahun ajaran 2013/2014 nilai rata-rata Bahasa Indonesia 7,86 ; Matematika 8,94; IPA 8,46. Dan pada tahun ajaran 2014/2015 nilai rata-rata Bahasa Indonesia 81,36; Matematika 83,80 dan IPA 76,60.

Dari data di atas dapat dilihat nilai tertinggi dan terendah siswa pada tahun ajaran 3 tahun terakhir ini. Dimana anak semakin tahun nilai ujiannya semakin menurun. Atas dasar itulah penulis tertarik untuk mengadakan penelitian dengan judul "Hubungan Lingkungan Masyarakat Tempat Wisata Terhadap Motivasi Belajar Siswa SDN 8 Tuk-Tuk Kecamatan Simanindo".

\section{METODE PENELITIAN}

Jenis penelitian ini adalah penelitian korelasional yang menjelaskan hubungan antara variabel-variabel, yaitu lingkungan masyarakat daerah wisata sebagai variabel bebas (X) dan motivasi belajar siswa sebagai variabel terikat (Y).

Populasi adalah jumlah keseluruhan obyek penelitian yang menjadi sumber data. Menurut Arikunto (2013:173) "Populasi adalah keseluruhan subjek penelitian”. Adapun yang menjadi populasi dalam penelitian ini adalah siswa SDN 8 Tuk-Tuk yang berjumlah 70 orang yang terdiri dari 3 kelas yaitu kelas IV, V dan VI. Untuk kelas IV berjumlah 23 orang, kelas V berjumlah 27 orang, dan kelas VI berjumlah 20 orang.

Sampel adalah sebagian dari jumlah populasi yang dipandang dapat mewakili populasi dan dapat dijadikan sebagian sumber data. Menurut Arikunto (2013:174) mengemukakan bahwa "Apabila subjeknya kurang dari 100 orang, lebih baik diambil semua sehingga penelitiannya merupakan penelitian populasi”.

Sampel dalam penelitian ini adalah siswa SDN 8 Tuk-Tuk kelas Effendi Manalu: Hubungan Lingkungan ... jenuh yaitu semua anggota populasi digunakan sebagai sampel yang berjumlah 70 orano siciva

Yang men penelitian ini adal: 
a. Variabel bebas (X) : Lingkungan masyarakat daerah wisata

b. Variabel terikat (Y) : Motivasi belajar siswa

Dokumentasi merupakan salah satu langkah atau teknik yang digunakan untuk mengumpulkan data. Langkah yang digunakan peneliti untuk mendapatkan data tentang banyaknya siswa yang melanjut ke jenjang yang lebih tinggi.
Angket merupakan sejumlah pertanyaan tertulis yang digunakan untuk memperoleh informasi dari responden dalam arti laporan tentang pribadinya, atau hal-hal yang ia ketahui (2013:194). Peneliti akan menggunakan angket tertutup yaitu pertanyaan-pertanyaan yang sudah disediakan jawabannya sehingga responden tinggal memilih jawaban yang sesuai.

Tabel 1. Tabel Kisi-Kisi Angket

\begin{tabular}{|c|c|c|c|}
\hline $\mathrm{NO}$ & Variabel & Indikator & No item \\
\hline 1 & $\begin{array}{l}\text { Lingkungan } \\
\text { Masyarakat }\end{array}$ & $\begin{array}{ll}\text { 1. } & \text { Kegiatan di luar sekolah } \\
\text { 2. Lingkungan } \\
\text { 3. Teman bermain } \\
\text { 4. Faktor kunjungan } \\
\text { wisatawan }\end{array}$ & $\begin{array}{l}1,2,3,5 \\
6,7,8,11,12,14,18,19,20 \\
4,13,15,16,17 \\
9,10\end{array}$ \\
\hline 2 & $\begin{array}{l}\text { Motivasi } \\
\text { Belajar }\end{array}$ & $\begin{array}{ll}\text { 1. } & \text { Keluarga } \\
\text { 2. } & \text { Belajar } \\
\text { 3. } & \text { Tugas rumah } \\
\text { 4. Semangat dalam diri } \\
\text { 5. Mengikuti pelajaran di } \\
\text { sekolah } \\
\text { 6. Lingkungan sekolah } \\
\text { 7. } \\
\text { Buku pelajaran }\end{array}$ & $\begin{array}{l}5,6 \\
1,3,4,13 \\
7,8,9,10,19 \\
2,8 \\
11,12,15,16,20 \\
\\
14,18 \\
17\end{array}$ \\
\hline
\end{tabular}

Untuk mengetahui validitas dan realibilitas angket dilakukan uji coba instrument pengambilan data. Adapun uji instrument yaitu:

Menurut Arikunto (2013:211) "Validitas adalah suatu ukuran yang menunjukkan tingkat-tingkat kevalidan atau kesahihan sesuatu instrumen. Suatu instrumen yang valid atau sahih mempunnyai validitas tinggi. Sebaliknya, instrumen yang kurang valid berarti memiliki validitas rendah". Untuk mengetahui validitas instrumen digunakan rumus korelasi product moment yaitu :

$$
\mathrm{r}_{\mathrm{xy}}=\frac{n \sum x y-\left(\sum x\right)\left(\sum y\right)}{\sqrt{\left\{n \sum_{x} 2\left(\Sigma_{x} 2\right)\right\}\left\{n \Sigma_{y} 2\left(\Sigma_{y}^{2}\right)^{2}\right\}}}
$$

Keterangan :

$r_{x y}=$ Koefisien korelasi antara variabel $\mathrm{X}$ dan $\mathrm{Y}$

$\mathrm{n}$ = Jumlah sampel 
$\sum_{\mathrm{x}}=$ Jumlah skor variabel $\mathrm{X}$ (pengelolaan kelas)

$\sum_{\mathrm{y}}=$ Jumlah skor variabel Y (hasil belajar siswa)

Besarnya $\quad r_{x y} \quad$ hitung dikonsultasikan $r$ tabel dengan batas signifikan 5\%. Apabila didapat $\mathrm{r}_{\mathrm{xy}}$ hitung > $r$ tabel maka butir soal tergolong valid dan demikian sebaliknya.

Untuk reliablitas angket digunakan rumus koefisien alpha

$$
\mathrm{r}_{11}=\left[\frac{k}{(k-1}\right]\left[1-\frac{\sum \alpha_{b}^{2}}{\alpha_{1}^{2}}\right]
$$

Keterangan :

$\mathrm{r}_{11}=$ Reliablitas instrumen

$\mathrm{k}$ = Banyaknya butir pertanyaan

$\sum \alpha_{b}^{2}=$ Jumlah variasi butir

$\alpha_{1}^{2}=$ Variasi total

Untuk mencari butir digunakan rumus :

$$
\sigma_{1}^{2}=\frac{\sum x^{2}-\frac{\left(\sum x\right)^{2}}{N}}{N}
$$

Sedangkan mencari variasi total dapat dicari dengan rumus :

$$
\sigma_{1}^{2}=\frac{\sum y^{2}-\frac{\left(\sum y\right)^{2}}{N}}{N}
$$

Bila $r$ hitung $>r$ tabel pada ESJ VOLUME 6, NO. 1, DESEMBER 2016 Teknik analisis data adalah
cara untuk memudahkan atau menyederhanakan data ke dalam bentuk yang lebih mudah dibaca dan dimengerti. Data dari variabel $X$ dan variabel Y ini dianalisis menggunakan analisis deskriftif, dan analisis data statistik, untuk itu langkah-langkah yang harus ditempuh sebagai berikut:

\section{Analisis Deskriftif}

Analisis Deskriftif bertujuan untuk menunjukkan sebuah data. Untuk itu dilakukan penelitian untuk mencoba mean, modus, dan media, serta simpangan baku. Kemudian data dikelompokkan serta di buat dalam tabel frekuensi. Kemudian diberi tafsiran sesuai apa adanya.

2. Uji korelasi

Untuk menguji korelasi antara variabel $\mathrm{X}$ dan variabel $\mathrm{Y}$ dilakukan dengan menggunakan rumus korelasi Product Moment menurut Suharsimi (2009:171) sebagai berikut:

$$
\mathrm{r}_{\mathrm{xy}}=\frac{n \sum x y-\left(\sum x\right)\left(\sum y\right)}{\sqrt{\left\{n \sum x^{2}\left(\sum x^{2}\right)\right\}\left\{n \sum y^{2}\left(\sum y^{2}\right)^{2}\right\}}}
$$

Keterangan :

$\mathrm{r}_{\mathrm{xy}}=$ Koefisien antara variabel $\mathrm{X}$ dan Y

$\Sigma^{\mathrm{x}}=$ Jumlah skor variabel $\mathrm{X}$ (pengelolaan kelas)

$\sum_{\mathrm{y}}=$ Jumlah skor variabel Y (hasil belajar siswa)

Effendi Manalu: Hubungan Lingkungan ...

$\mathrm{n} \quad=$ Jumlah sampel

3. Uji Hipotesis

Untuk mer

dirumuskan, ma e-ISSN 2355-1747 
dibuktikan dengan menguji signifikasi dari koefisien dengan uji-t, yang diuraikan Riduwan (2010:229) sebagai berikut:

$$
\mathrm{t}=\frac{r \sqrt{n-2}}{\sqrt{1-r^{2}}}
$$

Keterangan :

$\mathrm{t}$ = harga yang hitung dan menujukkan nilai standar deviasi dari distribusi tabel $\mathrm{t}$

$\mathrm{r}=$ koefisien korelasi

$\mathrm{n}$ = jumlah responden

Hipotesis diterima jika t hitung $>\mathrm{t}(1-\alpha)$ pada $\alpha=0,05$ dengan $\mathrm{dk}=\mathrm{n}$ - 2. Jika t hitung < $\mathrm{t}(1-\alpha)$, maka hipotesis ditolak.

Tabel 2. Interpretasi Koefisien Korelasi

\begin{tabular}{|c|c|}
\hline Interval koefisien & $\begin{array}{c}\text { Tingkat } \\
\text { Hubungan }\end{array}$ \\
Antara $0,800-1,000$ & Sangat Kuat \\
Antara $0,600-0,799$ & Kuat \\
Antara $0,400-0,599$ & Cukup \\
Antara $0,200-0,399$ & Rendah \\
Antara $0,000-0,199$ & Sangat Rendah \\
\hline
\end{tabular}

Penelitian ini dilaksanakan di SD 8 Tuk-tuk yang berlokasi di Desa Tuk-tuk, Kecamatan Simanindo.
SDN 8 Tuk-Tuk terletak di jalan ringroad Tuk-Tuk Siadong. Letak SDN 8 ini sangat strategis, karena dikelilingi oleh pepohonan, taman dan dilintasi oleh berbagai kendaraan umum. Jumlah siswa kelas IV, V, VI sebanyak 70 orang.

SDN 8 Tuk-Tuk memiliki fasilitas yang memadai dalam melaksanakan proses belajar mengajar. Sekolah ini memiliki 7 kelas, 1 kantor kepala sekolah, 1 perpustakaan, 2 kamar mandi siswa, 1 kamar mandi guru, 1 kamar mandi tamu. Di sekolah ini juga terdapat tempat parkiran dan kantin.

Sebelum dilaksanakan penelitian ini, penulis terlebih dahulu mengadakan persiapan yang berkaitan dengan administrasi penelitian yaitu:

a. Memperoleh izin dari Fakultas Ilmu Pendidikan UNIMED yang disetujui oleh PD 1 FIP UNIMED yang ditujukan kepada SDN 8 Tuk-Tuk.

b. Meminta izin kepada pihak sekolah SDN 8 Tuk-Tuk yang diawali dengan pertemuan secara formal dengan kepala sekolah untuk meminta kesediaan memberikan izin dalam mengadakan penelitian berdasarkan surat izin penelitian yang telah dikeluarkan UNIMED.

c. Setelah memperoleh izin, kepala sekolah menunjuk wali kelas yang membantu dalam proses penelitian. 
d. Selanjutnya penulis mempersiapkan alat ukut yang digunakan dalam penelitian berupa angket hubungan lingkungan masyarakat daerah wisata terhadap motivasi belajar siswa yang telah diphotocopy sesuai kebutuhan yang akan digunakan.

e. Pelaksanaan pengumpulan data dilakukan peneliti pada tanggal 15 Januari 2016 dengan menyebarkan angket kepada siswa.

f. Setelah siswa mengisi angket.

g. Peneliti mengumpulkan kembali dan setelah dilakukan perhitungan angket tersebut sesuai jumlah yang disebarkan dengan jumlah sudah dikumpulkan.

h. Selanjutnya peneliti melakukan pengolahan data angket yang telah dikumpulkan.

Pelaksanaan uji coba angket tentang lingkungan masyarakat daerah wisata dan motivasi belajar siswa dalam mengikuti kegiatan belajar mengajar dilaksanakan pada tanggal 15 Januari 2016. Uji coba dilaksanakan kepada 70 orang siswa. Angket uji coba disebarkan kepada siswa. Setelah angket dibagikan kepada seluruh siswa, peneliti membacakan petunjuk pengisian angket kepada siswa. Setelah siswa mengerti akan maksud dan tujuan dari angket tersebut, maka penulis membacakan satu persatu isi angket tersebut dan siswa diminta untuk mengisi jawaban pada lembar angket yang disediakan. Pada saat penelitian berlangsung peneliti tidak mengalami kesulitan, hanya ada beberapa siswa yang kurang mengerti maksud dari beberapa soal dalam angket tersebut, namun peneliti dapat mengatasinya dengan memberikan penjelasan dan contoh dalam kehidupan sehari-hari.

Setelah angket terkumpul, selanjutnya dilakukan penilaian terhadap angket dengan cara membuat format nilai berdasarkan skor-skor yang ada pada setiap angketnya. Kemudian skor yang merupakan pilihan subjek pada setiap butir soal tersebut ditabulasikan dan melihat soal yang valid dan tidak valid. Soal yang tidak valid dan tidak reliabel maka soal tersebut diganti dan di uji cobakan kembali dan ternyata soal yang sebelumnya dan soal yang diganti valid. Kemudian dilakukan pengumpulan data melalui instrumen. Deskripsi data yang disajikan menginformasikan rata-rata (mean), Effendi Manalu: Hubungan Lingkungan ... minimum.

Berdasarkan data penelitian yang di dapat dari hasil penyebaran angket tentang lingkungan masyarakat daerah wisata maka diperoleh skor maksimum 20 dan skor minimum 9. Diperoleh skor rata_rats $(\bar{Y})-11 \mathrm{Q}$ simpangan baku ( p-ISSN 2407-4934 $(\mathrm{Md})=14,76 \mathrm{~d}$ 16,92. Data yang uperoien selanjutnya di buat ke dalam tabel 
distribusi frekuensi, yang secara

ringkas dapat di lihat pada tabel 4.

Tabel 4. Daftar Distribusi Frekuensi Data Kelompok Lingkungan Masyarakat Daerah Wisata (X)

\begin{tabular}{|c|c|c|c|}
\hline No & Kelas Interval & F & Persentase \\
\hline 1 & $9-10$ & 4 & $5,71 \%$ \\
\hline 2 & $11-12$ & 9 & $12,86 \%$ \\
\hline 3 & $13-14$ & 19 & $27,14 \%$ \\
\hline 4 & $15-16$ & 15 & $21,43 \%$ \\
\hline 5 & $17-18$ & 19 & $27,14 \%$ \\
\hline 6 & $19-20$ & 4 & $5,71 \%$ \\
\hline \multicolumn{2}{|c|}{} & $\mathbf{7 0}$ & $\mathbf{1 0 0 \%}$ \\
\hline
\end{tabular}

Pada tabel 4.1 di atas menunjukkan bahwa terdapat 19 orang $(27,14 \%)$ yang berada pada skor rata-rata, 13 orang $(18,57 \%)$ yang berada di bawah rata-rata, dan 38 orang $(54,28 \%)$ yang berada di atas rata-rata. Lebih jelasnya dapat di lihat pada grafik 4 berikut:

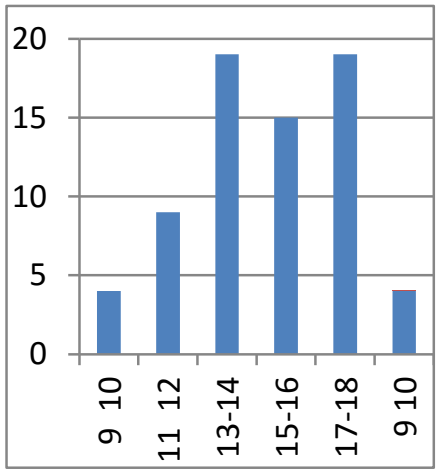

\section{Grafik 4. Histogram Lingkungan Masyarakat Daerah Wisata}

Pada grafik 4 di atas, menunjukkan bahwa pada kelas interval 13-14 merupakan grafik skor rata-rata dengan jumlah siswa 19 orang. Kelas interval 9-10 dan kelas interval 11-12 merupakan grafik yang berada dibawah skor rata-rata dengan jumlah siswa 13 orang.Dan kelas interval 15-16 sampai kelas interval 19-20 merupakan grafik yang berada di atas skor rata-rata dengan jumlah siswa sebanyak 38 orang.

Hasil analisis data motivasi belajar siswa SDN 8 Tuk-Tuk diperoleh skor maksimum 20 dan skor minimum 5. Hasil perhitungan pada lampiran 4 diperoleh skor rata-rata $(\bar{X})$ $=15,2$, simpangan baku $(\mathrm{s})=2,987$, median $(\mathrm{Md})=15,55$ dan modus $(\mathrm{Mo})$ $=16,92$. Data yang diperoleh selanjutnya di buat ke dalam tabel distribusi frekuensi, yang secara

ESJ VOLUME 6, NO. 1, DESEMBER 2016 


\begin{tabular}{|c|c|c|c|}
\hline No & Kelas Interval & F & Persentase \\
\hline 1 & $5-6$ & 1 & $1,43 \%$ \\
\hline 2 & $7-8$ & 2 & $2,86 \%$ \\
\hline 3 & $9-10$ & 2 & $2,86 \%$ \\
\hline 4 & $11-12$ & 5 & $7,14 \%$ \\
\hline 5 & $13-14$ & 16 & $22,85 \%$ \\
\hline 6 & $15-16$ & 17 & $24,28 \%$ \\
\hline 7 & $17-18$ & 21 & $30 \%$ \\
\hline 8 & $19-20$ & 6 & $8,57 \%$ \\
\hline \multicolumn{2}{|l}{ Jumlah } & $\mathbf{7 0}$ & $\mathbf{1 0 0 \%}$ \\
\hline
\end{tabular}

Pada tabel di atas menunjukkan bahwa terdapat 2 orang $(2,86 \%)$ yang berada pada skor ratarata, 3 orang $(4,29 \%)$ yang berada di bawah rata-rata, dan 65 orang $(92,84 \%)$ yang berada di atas rata-rata. Lebih jelasnya dapat di lihat pada grafik berikut:

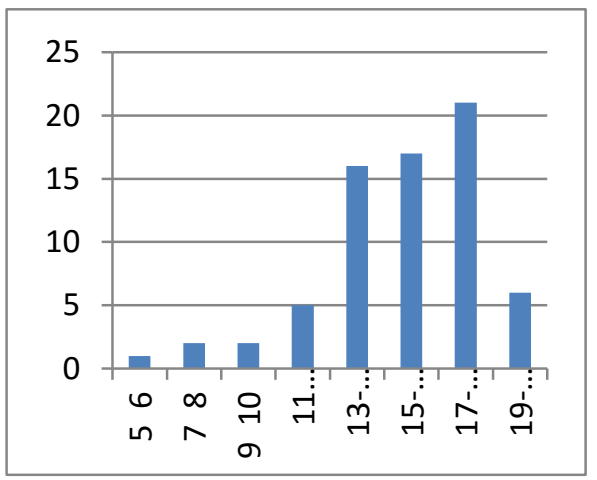

Grafik 5. Histogram Motivasi Belajar

Pada grafik 5 di atas, menunjukkan bahwa pada kelas interval 9-10 merupakan grafik skor rata-rata dengan jumlah siswa 2 orang. Kelas interval 5-6 dan kelas interval 78 merupakan grafik yang berada dibawah skor rata-rata dengan jumlah siswa 3 orang. Dan kelas interval 1112 sampai kelas interval 19-20 merupakan grafik yang berada di atas skor rata-rata dengan jumlah siswa sebanyak 65 orang.

Untuk melengkapi deskripsi data penelitian dilakukan pengujian kecenderungan dari masing-masing variabel penelitian yang dikategorikan pada 4 (empat) kategori, yaitu kategori tinggi, sedang, cukup, dan kurang. Perhitungan selengkapnya dapat di lihat di lampiran 12 dan 13.

Tabel 6. Uji Kecenderungan Lingkungan Masyarakat Daerah Wisata $(X)$

\begin{tabular}{|c|c|c|c|}
\hline $\begin{array}{c}\text { Interval } \\
\text { Skor }\end{array}$ & Frekuensi & $\begin{array}{c}\text { Persentase } \\
(\%)\end{array}$ & Kategori \\
\hline$\geq 17$ & 23 & $32,86 \%$ & Tinggi \\
\hline $15-17$ & 10 & $14,28 \%$ & Sedang \\
\hline $13-15$ & 24 & $34,28 \%$ & Cukup \\
\hline$<13$ & 13 & $18,57 \%$ & Kurang \\
\hline
\end{tabular}

Effendi Manalu: Hubungan Lingkungan ...

Berdasarkan data pada tabel di atas, dapat dijabarkan bahwa untuk variabel lingkungan masyarakat daerah wisata, skor dinvatakan tinggi ketika mencapai ¿ p-ISSN 2407-4934 e-ISSN 2355-1747 
23 orang sebesar 32,86\%, skor dinyatakan sedang ketika mencapai nilai $15-17$ berjumlah 10 orang sebesar 14,28\%, skor dinyatakan cukup ketika mencapai nilai $13-15$ berjumlah 24 orang sebesar $34,28 \%$, dan skor dinyatakan kurang ketika mencapai nilai $<13$ berjumlah 13 orang sebesar $18,57 \%$.

$$
\text { Grafik tentang uji }
$$

kecenderungan etos kerja guru dapat di lihat pada grafik 6 berikut:

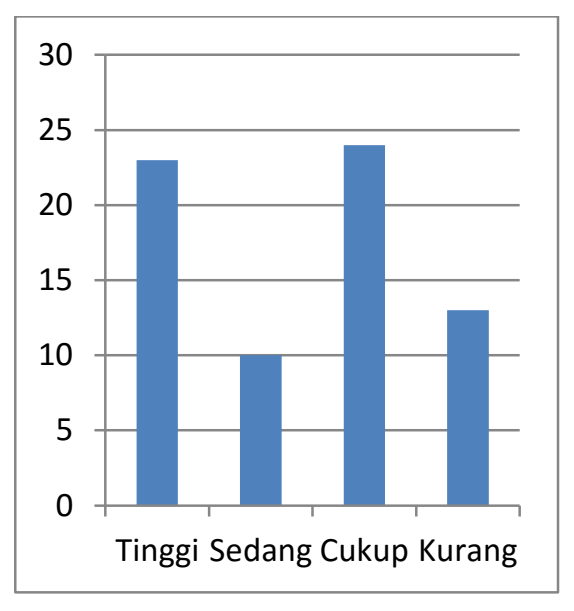

\section{Grafik 6. Histogram Uji} Kecenderungan Lingkungan Masyarakat Daerah Wisata $(X)$

Berdasarkan grafik di atas, siswa yang memiliki skor tinggi berjumlah 23 orang, skor sedang berjumlah 10 orang, skor cukup berjumlah 24 orang dan skor kurang berjumlah 13 orang.

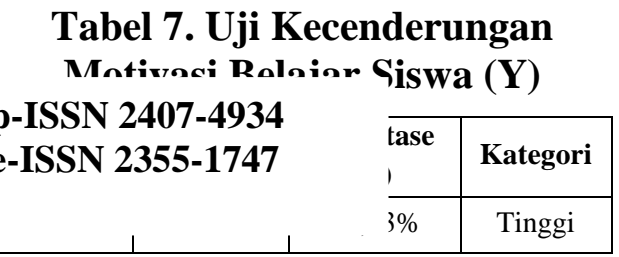

\begin{tabular}{|c|c|c|c|}
\hline $15-18$ & 22 & $31,43 \%$ & Sedang \\
\hline $12-15$ & 27 & $38,57 \%$ & Cukup \\
\hline$<12$ & 6 & $8,57 \%$ & Kurang \\
\hline Jumlah & $\mathbf{7 0}$ & $\mathbf{1 0 0 \%}$ & \\
\hline
\end{tabular}

Berdasarkan data pada tabel di atas, dapat dijabarkan bahwa untuk variabel hasil belajar siswa, skor dinyatakan tinggi ketika mencapai $\geq 18$ yang berjumlah 15 orang sebesar $21,43 \%$, skor dinyatakan sedang ketika mencapai nilai 15-18 berjumlah 22 orang sebesar $31,43 \%$, skor dinyatakan cukup ketika mencapai nilai 12-15 berjumlah 27 orang sebesar $38,57 \%$, dan skor dinyatakan kurang ketika mencapai nilai $<12$ berjumlah 6 orang sebesar 8,57\%. Grafik tentang uji kecenderungan hasil belajar siswa dapat di lihat pada grafik 7 berikut:

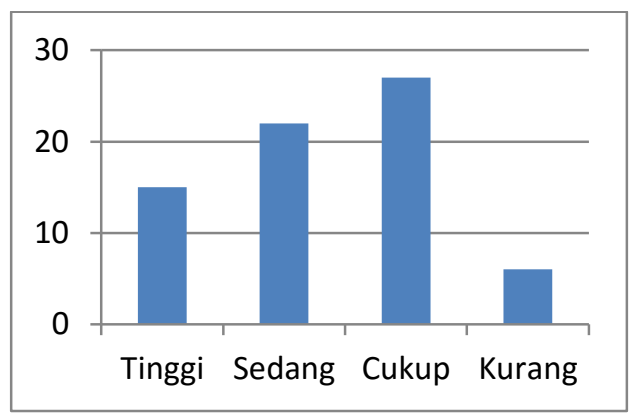

Grafik 7. Histogram Uji

Kecenderungan Motivasi Belajar Siswa (Y)

Berdasarkan grafik di atas, siswa yang memiliki skor tinggi berjumlah 15 orang, skor sedang berjumlah 22 orang, skor cukup berjumlah 27 orang dan skor kurang berjumlah 6 orang. 
Pengujian analisis data dimaksudkan sebagai uji persyaratan untuk menggunakan teknik analisis regresi sebelum data di analisis. Persyaratan yang dilakukan adalah uji normalitas dan uji homogenitas.

Uji normalitas dipergunakan untuk menguji apakah data skor variabel lingkungan masyarakat daerah wisata dan variabel motivasi belajar siswa berdistribusi normal atau tidak. Pengujian ini dilakukan menggunakan uji Liliefors. Berikut disajikan hasil analisis normalitas data penelitian pada Tabel 4.5 (perhitungan selengkapnya lihat di lampiran 14 dan $15)$.

\section{Tabel 8. Hasil Analisis Normalitas} Data Penelitian

\begin{tabular}{|c|c|c|c|}
\hline No. & $\begin{array}{c}\text { Variabel } \\
\text { Penelitian }\end{array}$ & $L_{\text {hitung }}$ & $L_{\text {tabel }}$ \\
\hline 1. & $\begin{array}{c}\text { Lingkungan } \\
\text { masyarakat } \\
\text { daerah wisata }\end{array}$ & 0,105 & 0,106 \\
\hline 2. & $\begin{array}{c}\text { Motivasi } \\
\text { belajar siswa }\end{array}$ & 0,016 & 0,106 \\
\hline
\end{tabular}

Dari tabel di atas diperoleh $L_{\text {hitung }}<L_{\text {tabel }}$ pada taraf nyata $a=$ 0,05. Dengan demikian dapat disimpulkan bahwa distribusi data dari kedua variabel penelitian adalah berdistribusi normal sehingga dapat digunakan rumus product moment.

Pengujian homogenitas dilakukan untuk mengetahui apakah data dalam variabel $\mathrm{X}$ dan variabel $\mathrm{Y}$ bersifat homogen atau tidak. Adapun dalam penelitian, pengujian homogenitas dilakukan dengan cara uji F (perhatikan lampiran 16). Hasil uji homogenitas dari penelitian ini dapat dilihat pada tabel 4.6.

Tabel 9. Hasil Analisis Homogenitas Data Penelitian

\begin{tabular}{|l|c|c|c|c|c|}
\hline Variabel & Varian & $\mathbf{d b}_{\mathbf{1}}$ & $\mathbf{d b}_{\mathbf{2}}$ & $\mathbf{F}_{\text {hitung }}$ & $\mathbf{F}_{\text {tabel }}$ \\
\hline $\begin{array}{l}\text { Lingkungan } \\
\text { Masyarakat } \\
\text { Daerah } \\
\text { Wisata (X) }\end{array}$ & 6,903 & $\begin{array}{c}70- \\
1\end{array}$ & \multirow{2}{*}{0,77} & 3,98 \\
\cline { 1 - 4 } $\begin{array}{l}\text { Motivasi } \\
\text { Belajar } \\
\text { Siswa (Y) }\end{array}$ & 8,924 & & $\begin{array}{c}70- \\
1\end{array}$ & & \\
\hline
\end{tabular}

Berdasarkan pada tabel 4.6, maka jelas terlihat bahwa $F_{\text {hitung }}$ pada penelitian ini memiliki nilai 4,35. Sementara $F_{\text {tabel }}$ dengan signifikan 0,05 dengan $\mathrm{db}_{1}=70-1$ dan $\mathrm{db}_{1}=70$ 1 memiliki nilai 3,98. Maka $\mathrm{F}_{\text {hitung }}<\mathrm{F}_{\text {tabel }}$ dapat disimpulkan bahwa data dari variabel penelitian $\mathrm{X}$ dan Y adalah Homogen. Setelah diketahui bahwa data adalah normal dan homogen, maka langkah selanjutnya adalah dengan menguji korelasi dengan Product Moment.

Setelah dilakukan uji prasyarat, maka selanjutnya dicari hubungan daerah masyarakat daerah wisata terhadap motivasi belajar siswa SDN 8 Tuk-Tuk, apakah hubungan kedua variabel 1 (meyakinkan) at p-ISSN 2407-4934 dilakukan dengan e-ISSN 2355-1747 koefisien korelasi dengan rumus Product Moment. 
Berdasarkan hasil perhitungan (dapat dilihat pada lampiran 17), diperoleh $r_{x y}$ sebesar 0,289. Pada taraf signifikan 5\% dan $\mathrm{N}=70$ dengan hasil perhitungan $r_{x y}>r_{\text {tabel }}$ yaitu 0,289 > 0,235 . Sehingga dapat disimpulkan bahwa terdapat hubungan antara lingkungan masyarakat daerah wisata terhadap motivasi belajar siswa SD 8 Tuk-Tuk.

Dari perhitungan diperoleh koefisien determinasi $\left(\mathrm{r}^{2}\right)$ sebesar $(0,289)^{2}=0,083$ yang berarti $8,3 \%$. Sehingga dengan demikian besarnya persentase hubungan lingkungan masyarakat daerah wisata dengan motivasi belajar siswa sebesar 8,3\%. Sedangkan 91,7\% dipengaruhi oleh faktor-faktor lain. Untuk perhitungannya ada pada lampiran 18 . Pengujian untuk mengetahui hubungan variabel lingkungan masyarakat daerah wisata dengan motivasi belajar siswa SDN 8 TukTuk digunakan analisis korelasi product moment sedangkan untuk menguji keberartiannya digunakan uji t. Penjelasan korelasi variabel ini dapat dilihat pada lampiran 5 . Rangkuman perhitungan dapat dilihat pada tabel 10:

Tabel 10. Rangkuman Hasil Analisa Korelasi X dengan Y dan Uji Keberartiannya (t)

\begin{tabular}{|c|c|c|c|c|}
\hline Korelasi & $\begin{array}{c}\text { Koefisiesn } \\
\text { Korelasi }\end{array}$ & $\begin{array}{c}\text { Koefisien } \\
\text { Determinasi (r) }\end{array}$ & T $_{\text {hitung }}$ & T $_{\text {tabel }}$ \\
\hline $\mathbf{R}_{\mathbf{x y}}$ & 0,289 & 8,3 & 2,49 & 1,995 \\
\hline
\end{tabular}

Dari tabel di atas, menunjukkan bahwa koefisien korelasi antara lingkungan masyarakat daerah wisata dengan motivasi belajar siswa sebesar 0,289 dengan koefisien determinasi sebesar 8,3\%. Melalui uji $\mathrm{t}$ yang telah dilakukan pada taraf signifikansi 0,05 adalah 1,995, maka diperoleh $t_{\text {hitung }}=2,49$ dan $\mathrm{t}_{\text {tabel }}=$ 1,995. Ternyata $t_{\text {hitung }}>t_{\text {tabel. }}$. Hal ini menunjukkan bahwa terdapat hubungan positif antara lingkungan msayarakat daerah wisata terhadap motivasi belajar siswa SDN 8 Tukp-ISSN 2407-4934 e-ISSN 2355-1747

\section{Pembahasan Hasil Penelitian}

Berdasarkan hasil penelitian yang diperoleh yaitu untuk mengetahui hubungan lingkungan masyarakat terhadap motivasi belajar SDN 8 Tuk-Tuk. Maka peneliti mengadakan pengumpulan data dengan menggunakan angket yang disebarkan kepada 70 orang siswa (sampel). Pengambilan sampel secara total. Berdasarkan data yang diperoleh dari hasil sebaran angket ditemukan bahwa lingkungan masyarakat daerah wisata SDN 8 Tuk-Tuk termasuk dalam kategori "sedang" dengan nilai rata-rata 14,8. Sedangkan motivasi 
belajar siswa SDN 8 Tuk-Tuk termasuk dalam kategori "sedang" dengan nilai rata-rata 15,2. Dan setelah dilakukan pengujian uji prasyarat diperoleh bahwa lingkungan masyarakat daerah wisata dan motivasi siswa berdistribusi normal dan mempunyai varians yang homogeny (sejenis).

Kemudian

perhitungan korelasi diperoleh hubungan lingkungan masyarakat daerah wisata terhadap motivasi belajar siswa mempunyai tingkat korelasi yang tinggi. Dan kemudian dilakukan uji $t$ dipeoroleh $t_{\text {hitung }}>t_{\text {tabel }}$. Hal ini menunjukkan bahwa terdapat hubungan yang signifikan antara lingkungan msayarakat daerah wisata terhadap motivasi belajar siswa SDN 8 Tuk-Tuk dapat diterima. Artinya semakin baik lingkungan masyarakat daerah wisata, maka akan semakin baik pula motivasi belajar siswa.

\section{SIMPULAN}

Berdasarkan hasil penelitian yang telah dilakukan maka dapat diperoleh kesimpulan yaitu lingkungan masyarakat daerah wisata tergolong sedang, yakni dengan nilai rata-rata sebesar 14,8 dan standar deviasi sebesar 1,92. Sedangkan motivasi belajar siswa tergolong sedang, yakni dengan nilai rata-rata 15,2 dan standar deviasi sebesar2,93. Dari hasil perhitungan korelasi yang telah dilakukan, lingkungan masyarakat daerah wisata berhubungan dengan motivasi belajar siswa yaitu $r_{x y}>r_{\text {tabel }}$ yaitu $0,289>$ 0,235 . Hal ini menunjukkan bahwa hubungan lingkungan masyarakat daerah wisata terhadap motivasi belajar siswa mempunyai tingkat korelasi yang tinggi.

Sedangkan dari uji t yang telah dilakukan pada taraf signifikansi 0,05 adalah 1,995, maka diperoleh $\mathrm{t}_{\text {hitung }}=$ 2,49 dan $t_{\text {tabel }}=1,995$. Ternyata $t_{\text {hitung }}$ $>t_{\text {tabel}}$. Hal ini menunjukkan bahwa terdapat hubungan yang signifikan antara lingkungan masyarakat daerah wisata terhadap motivasi belajar siswa SDN 8 Tuk-Tuk dapat diterima. Artinya semakin baik lingkungan masyarakat daerah wisata, maka akan semakin baik pula motivasi belajar siswa.

Berdasarkan hasil penelitian yang telah dilakukan, maka peneliti memberikan saran sebagai berikut:

1. Bagi siswa, hendaknya terus berusaha untuk meningkatkan motivasi belajar dengan cara lebih rajin belajar baik di sekolah maupun di rumah.

Effendi Manalu: Hubungan Lingkungan ... semangat belajar terhadap siswa, agar dapat membangkitkan motivasi dari dalam diri maunun dari luar diri s p-ISSN 2407-4934

3. Bagi sekolah e-ISSN 2355-1747 meningkatkan кuaıtas sıswa dengan selalu memotivasi siswa agar lebih aktif dalam belajar misalnya selalu memberi nasehat 
dan bimbingan bagi siswa yang kurang dapat mengikuti pembelajaran.

4. Bagi peneliti selanjutnya, agar lebih mengembangkan penelitian ini di sekolah dengan menghubungkan kepada prestasi belajar siswa sehingga akan diperoleh suatu data yang lebih kompleks dan optimal.

\section{DAFTAR RUJUKAN}

Ahmadi, H.Abu. 2007. Sosiologi Pendidikan. Jakarta: PT.Rineka Cipta.

http://limnologi.lipi.go.id/danau/profi 1.php?id_danau=sum_toba\&tab =gambaran\%20umum. (diakses pada tanggal 8 Oktober 2015 pukul 21.13 WIB).

http://www.indonesia.travel/id/destin ation/735/desa-tuktuk-siadong. (diakses pada tanggal 25 Oktober 2015 pukul 11.47 WIB).

http://www.wisatakandi.com/2010/08 /pengertian-azas-dan-tujuanpariwisata.html (diakses pada tanggal 24 November 2015 nıkul 1747 )

p-ISSN 2407-4934

e-ISSN 2355-1747 'engembangan

Wisata Pantai

Sigandu Kabupaten Batang, dalam repository.undip.ac.id diakses pada 28 Oktober 2015 pukul 21 : 26 WIB.
Leo, Sutanto. 2013. Kiat Jitu Menulis Skripsi, Tesis, dan Disertasi. Jakarta: Erlangga.

Oemar Hamalik, et al. 2001. Proses Beelajar Mengajar. Bandung: PT Bumi Aksara.

Pulungan Intan \& Istarani. 2015. Ensiklopedi Pendidikan. Medan: Media Persada.

Slameto. 2010. Belajar dan FaktorFaktor yang Mempengaruhi. Jakarta : PT.Rineka Cipta.

Supardiyanto, Teguh. Penggunaan Metode Karya Wisata dalam Upaya Meningkatkan Motivasi Belajar Siswa Pada Bidang Studi Agama Islam.Dalam (https.files.wordpress.com\%2F 2010\%2F05\%2Fpenggunaanmetode-karya-wisata-dalamupaya-meningkatkan-motivasibelajar-siswa-pada-bidangstudi-agama-islam.doc\&usg). (diakses pada 28 September 2015 pukul 22.54 WIB). 